\title{
Partnerships for involving small-scale growers in commercial forestry: lessons from Australia and Indonesia
}

\author{
D. RACE, A.R. BISJOE, R. HAKIM, N. HAYATI, JULMANSYAH, A. KADIR, KURNIAWAN, P. KUSUMEDI, A.A. NAWIR, \\ NURHAEDAH, D.U. PERBATASARI, R. PURWANTI, D. ROHADI, H. STEWART, B. SUMIRAT and A. SUWARNO
}

Corresponding author: D. Race, Charles Sturt University, PO Box 789, Albury, New South Wales, 2640, Australia

Email: drace@csu.edu.au

\begin{abstract}
SUMMARY
The trade relationship between small-scale growers and processing companies often plays an important role in determining the nature and extent of benefits derived from commercial forestry, and the distribution of these benefits. Many strategies are used by individual small-scale growers, village communities, companies and government agencies to form partnerships to undertake commercial forestry - including outgrower schemes, land leasing by companies, and using intermediary brokers between small-scale growers and processors. This article reports on the key findings of a three-year research project that explored different business partnerships used in commercial forestry in Australia and Indonesia, and identified the critical factors for beneficial and enduring partnerships. The key lessons from this research are that, for many small-scale growers to form successful partnerships with other investors, they need:

- increased knowledge of the operations and components of commercial forestry;

- improved access to competitive markets;

- increased knowledge of the dynamics of forest product markets;

- improved capacity of local farmer forest groups to share experiences and information, and build their knowledge of commercial forestry; and

- reduced administrative and financial burden imposed by government on small-scale forestry operations.
\end{abstract}

Keywords: small-scale growers, company partnerships, commercial forestry, Australia, Indonesia

Travail d'équipe pour impliquer les petits planteurs dans la foresterie commerciale: leçons en provenance de l'Australie et de l'Indonésie

D. RACE, A.R. BISJOE, R. HAKIM, N. HAYATI, JULMANSYAH, A. KADIR, KURNIAWAN, P. KUSUMEDI, A.A. NAWIR, NURHAEDAH, D. U. PERBATASARI, R. PURWANTI, D. ROHADI, H. STEWARD, B. SUMIRAT et A.SUWARNO

Les relations commerciales entre les petits planteurs et les compagnies de traitement jouent souvent un rôle important dans la détermination de la nature et de l'étendue des bénéfices dérivés de la foresterie commerciale, et dans la distribution de ces bénéfices. Plusieurs sortes de stratégies sont utilisées par les petits planteurs individuels, les communautés villageoises, les compagnies et les agences gouvernementales pour former des équipes pour prendre en main la foresterie commerciale, en incluant les planteurs extérieurs, la location des terres par des compagnies, et en utilisant des intermédiaires entre les petits planteurs et les industries de traitement. Cet article présente les découvertes clés d'un projet de recherche vieux de trois ans qui a exploré différentes équipes commerciales utilisées dans la foresterie commerciale en Australie et en Indonésie. Il identifie les facteurs critiques permettant des équipes fructueuses et durables. Les leçons les plus importantes de cette recherche sont que, pour que plusieurs petits planteurs puissent former des équipes qui aient du succès avec d'autres investisseurs, il faut qu'ils aient:

- une connaissance accrue des opérations et des éléments de la foresterie commerciale;

- un accès amélioré aux marchés compétitifs;

- une connaissance plus poussée de la dynamique des marchés de produits forestiers;

- une capacité améliorée des groupes de fermiers locaux à partager leurs expériences et leurs informations, et à élargir leur compréhension de la foresterie commerciale; et

- une réduction du fardeau administratif et financier imposé par le gouvernement aux petites opérations forestières.

Asociaciones para fomentar la participación en la silvicultura comercial de cultivadores a pequeña escala: lecciones desde Australia e Indonesia

D. RACE, A.R. BISJOE, R. HAKIM, N. HAYATI, JULMANSYAH, A. KADIR, KURNIAWAN, P. KUSUMEDI, A.A. NAWIR, NURHAEDAH, D.U. PERBATASARI, R. PURWANTI, D. ROHADI, H. STEWART, B. SUMIRAT y A. SUWARNO

La relación comercial entre cultivadores a pequeña escala y empresas procesadoras desempeña a menudo un papel importante en determinar 
el carácter y alcance de los beneficios derivados de la silvicultura comercial, y la distribución de estos beneficios. Los individuos que cultivan a pequeña escala, las comunidades rurales, las empresas y los organismos gubernamentales utilizan muchas estrategias para formar asociaciones que les permita emprender operaciones de silvicultura comercial, incluyendo planes de franquicia para cultivadores, leasing de terrenos por parte de empresas, y el uso de agentes intermediarios entre cultivadores a pequeña escala y empresas procesadoras. Este estudio describe los resultados clave de un proyecto de investigación de tres años que exploró las diferentes asociaciones comerciales utilizadas en la silvicultura en Australia e Indonesia, e identificó los factores críticos para las asociaciones beneficiosas y duraderas. En cuanto a la formación de asociaciones exitosas entre cultivadores a pequeña escala y otros inversionistas, las lecciones más importantes de esta investigación demuestran que se necesita:

- mayor conocimiento de las operaciones y los componentes de la silvicultura comercial;

- mejor acceso a mercados competitivos;

- mayor conocimiento de la dinámica de mercados de productos forestales;

- mejoras en la capacidad de grupos de cultivadores forestales locales de compartir experiencias e información, y fortalecer sus conocimientos de la silvicultura comercial; y

- reducción de cargas administrativas y financieras impuestas por el gobierno a operaciones forestales a pequeña escala.

\section{PARTNERSHIPS VITAL FOR SUCCESSFUL FORESTRY}

The benefits from commercial forestry to rural communities are not always obvious. Indeed, the costs and benefits for communities, companies and government for commercial forestry are not always understood or distributed evenly - which makes it difficult to negotiate fair and viable partnerships for a range of stakeholders investing in forestry.

The trade relationship between small-scale growers (farmers and other non-corporate landholders) and processing companies often plays an important role in determining the nature and extent of benefits derived from commercial forestry, and the distribution of these benefits. Those interested in forestry development - both in industrialised and semi-industrialised countries - are becoming increasingly aware that the nature of the business partnership between forest companies/government and small-scale growers (e.g. farmers, village-based communities) is critical in determining whether forestry is environmentally sustainable, cost-effective and socially beneficial. Many strategies are used by individual farmers and village communities to form partnerships with companies or governments - including out-grower schemes (joint ventures), land leasing by companies, and using intermediary brokers between smallscale growers and processors (Arnold 1997, Mayers 2000, Nawir and Santoso 2005, Race and Curtis 1999, Race and Desmond 2002). Contracts between small-scale farmers and agribusiness (Gray and Lawrence 2001, Patrick 2004), and villagers and biodiversity conservation organisations (Mavhunga 2007, Vermeulen and Sheil 2007), are similarly complex - offering both benefits and risks to all partners.

Partnership arrangements for forestry, involving a variety of mechanisms and structures, are being used increasingly in Indonesia and Australia to link small-scale growers and timber processing companies, as companies with inadequate forest holdings or limited access to public forests seek to secure additional supplies to meet the increasing global demand for wood products. However, existing partnership arrangements vary considerably in their ability to be mutually beneficial. Not all partnerships are viewed as successful and poor grower-industry links are regularly identified as one of the major constraints to forestry development throughout the world - such as when growers emerge as 'price takers' in monopoly markets (Mayers and Vermeulen 2002). Rural villagers are often particularly wary of committing to risky long-term contracts, and so tend to avoid investing their time and physical resources (e.g. land) in forestry. Furthermore, it can encourage a view that commercial forestry is merely an activity to be involved in opportunistically and on a short-term basis, and so making villagers vulnerable to the temptation of exploitive, unsustainable - even illegal practices.

\section{Review of forestry partnerships}

In many countries, there is a wide variety of partnership arrangements that link a mix of growers (small and largescale), intermediary brokers and processors in commercial forestry (Curtis and Race 1998, Makarabhirom and Mochida 1999, Mayers and Vermeulen 2002, Nawir et al. 2003, Race and Desmond 2002, Thoms et al. 2006). Some of the reasons small-scale growers form partnerships with processors include to:

- have secure sale contracts (market access),

- receive technical and financial support,

- help secure land tenure and tree rights.

Some processors form partnerships with small-scale growers to:

- gain access to land or forests suited to commercial forestry,

- secure future timber supplies,

- strengthen positive relationships with local people by sharing the benefits of commercial forestry.

An example of one partnership between small-scale growers and a company that illustrates the multiple benefits is illustrated in Box 1.

The benefits of partnerships for commercial forestry need to be viewed against the costs or risks for different partners. Most of the literature highlights the costs or risks for small-scale farmers entering into partnerships with corporate entities, although equally there are costs and risks for companies and other partners. Rather than focusing on 


\section{BOX 1 PT Finnantara Intiga scheme Stora Enso Inhutani} III, West Kalimantan, Indonesia

The PT Finnantara Intiga out-grower scheme, run jointly by a Finnish and Indonesian company - Stora Enso Inhutani III, was developed to produce pulpwood and commenced in 1994. The scheme was initiated to avoid conflict with local people when land, owned by the government with local people holding traditional user rights, was approved for timber production under the Timber Estate Program of the Indonesian government.

The villagers contributed village land in return for an agreed annual rent, with many local people also employed under the scheme. The company provided all other inputs, including the seedlings and had responsibility for maintaining, harvesting and replanting of plantations. At harvest, 90 percent of the resource goes directly to the company, with the village retaining the other 10 percent of the plantation which they usually sold to the company at the market price. The company also provided villagers with seedlings of local multi-purpose trees and improved rubber tree clones, and has allocated resources for other projects considered part of community development, such as agricultural initiatives.

Under the scheme, villagers have planted Acacia mangium, A. crassicarpa and Eucalyptus pellita on grassland and in degraded forests.

equal partnerships where there are common goals and shared decisions, rights, responsibilities, roles and risks, Robinson (2007) argued that partnerships should aim to meet the expectations of each partner.

While having the goal to engage small-scale growers in commercial forestry via beneficial and fair partnership arrangements (i.e. partners having an equal capacity to negotiate the conditions of a partnership) is highly desirable, it can be difficult to achieve. Partnerships that simply mask and entrench an asymmetry of power between different partners will undermine the link between commercial forestry and community development - a link that is a common policy ambition of many governments.

\section{BACKGROUND TO THE RESEARCH PROJECT}

A three-year research project ${ }^{1}$ explored the different experiences of the stakeholders involved in very different partnerships in three locations. The research also sought to identify the key factors that contributed to 'successful' partnerships. The project focused its research on the forestry partnership arrangements in three locations:

- Sumbawa district in West Nusa Tenggara province of Indonesia;

- Bulukumba district in South Sulawesi province of

\section{Indonesia; and}

- Green Triangle region in south-east Australia.

These locations were selected as they represented different partnership arrangements, were where government was promoting community-based commercial forestry, and the research team (the authors) had familiarity with the local context. The partnership arrangements profiled in this article are deliberately diverse, and illustrate just some of the different mechanisms and relationships that can be included under the broad umbrella term - forestry partnerships.

\section{Locations for research}

In Sumbawa district (the term 'district' is used to refer to an area larger than that occupied by a single village, yet smaller than province or region), in West Nusa Tenggara province, the research team worked with local government forest officers, non-government organisations (NGOs) and local farmer forest groups to explore the nature of existing forestry partnership arrangements in the villages of Semamung and Lamenta. To overcome the steady degradation of the government's teak (Tectona grandis), mahogany (Swietenia macrophylla) and Sonokeling (Dalbergia latifolia) plantations, mainly due to unauthorised harvesting for fuelwood by local people, the Provincial and District forest staff have sought a closer relationship with the surrounding community.

In 1999, the Sumbawa Forestry and Estate District Office designated an area of 257 hectares of teak plantation on government-owned land as a Community Forest in the village of Semamung, in an attempt to foster a sense of 'ownership' amongst the local community, by providing access to forest products in return for undertaking silviculture and forest protection. The agreed potential forest products are for both household use and commercial sale. Currently, 177 farmers are members of the local farmer forest group. An agreement for a similar farmer-government partnership in Lamenta village was established in 2004 under the Social Forestry Program. Although the farmers and government forest officers are optimistic about the partnership, there are concerns that intermediary brokers, commonly referred to as 'middlemen' (people who purchase timber from growers and on-sell to processors), are receiving unfairly high prices for organising the harvest and transport of teak from the forests. Despite the current cooperation between the partners, there is also concern that the community does not have a secure right to harvest the teak on the government-owned lands.

In the Bulukumba district, in South Sulawesi province, the research team worked with local partners to explore the nature of an informal (verbal agreement) partnership arrangement between a private company and local farmers in two villages - Balong and Karassing. In the Bulukumba district, a private company (PT. PAL) has encouraged local

\footnotetext{
1 The research project - 'Community partnerships for plantation forestry: Enhancing rural incomes from forestry in eastern Indonesia and Australia', received core funding from the Australian Centre for International Agricultural Research (ACIAR), and was active during January 2005 and December 2007.
} 
farmers to grow timber trees on their private farmland to supply the veneer mill the company built in the district in 2001. With good growing conditions (harvest expected within 5-8 years) and some farmers already receiving pleasing financial returns, farm-based forestry has been established across nearly 12000 hectares -11 percent of the district's total land area.

The partnership arrangement between individual smallscale growers and the company is supported and facilitated by the Head of Bulukumba District Forest Office. In 2002, a forest farmer group initiated a partnership with the company to reach a supply-purchase agreement. Although there is still no written contract, the company continues to distribute free tree seedlings to farmers with the expectation by both partners that small-scale growers will sell their timber to the company, with harvesting expected to begin by 2008-2010. It is anticipated that farmers will continue with the current arrangement for selling timber, by selling their standing trees to intermediary brokers ('middlemen'), who then harvest and transport the logs to the company's mill. It is estimated that there are 12 separate 'middlemen' operating in the Bulukumba district that fulfil this role of harvesting and transporting logs.

The third location for research was the Green Triangle region, in south-east Australia. The region has a long history of commercial forestry, with the South Australian state government establishing large-scale pine (Pinus radiata) plantations from 1907, with the Victorian state government doing similarly from 1925. Commercial plantings of hardwood, such as blue gum (Eucalyptus globulus) were not established until 1991. By 2000, it was estimated that there was 224184 hectares of plantations, 69 percent comprised of softwoods (mostly $P$. radiata) and 31 percent of hardwoods (mostly E. globulus). This represents about 15 percent of Australia's total area of commercial forest plantations.

It is now common practice for large companies to operate managed investment schemes to attract urban people to invest funds for growing commercial blue gum plantations, with the land secured and trees managed by the company for sale at around age 10 years as logs or chipped pulpwood to processors. These companies usually prefer to purchase farmland to establish forestry plantations, yet will negotiate land-leasing partnership arrangements with individual landholders to gain access to additional high-quality land (usually paying landholders annual rent for use of the farmland, over a 20-year period which allows production of two tree-crops). Farm-based plantations account for about 30 percent of the region's total plantation area, although it is uncertain what proportion or area is grown under partnership between companies and landholders.

\section{Research process and methodology}

\section{Research team}

The project combined the research capabilities and expertise primarily of the Indonesian Forestry Research and Development Agency (FORDA) - Sulawesi, Center for
International Forestry Research (CIFOR), WWF - Indonesia (WWF), and Charles Sturt University (CSU) in Albury, Australia. The research team involved a core group of 16 researchers (the authors) with a range of expertise (i.e. socioeconomics, silviculture, policy analysis), who were engaged in the research on a part-time basis over a three-year period. A range of other research organisations, forestry agencies, non-government organisations and forestry companies, together with members of the local farmer forest groups both in Indonesia and Australia, were involved as research partners in each of the three research locations.

The project's analytical capacity was strengthened by a Project Advisory Group - which met once per year with the research team and comprised 12 senior researchers and managers from FORDA, provincial forest agencies, WWF, CIFOR and CSU. Partners and other interested people were informed of the project's progress and findings via a 6-monthly two-page newsletter (written in English and Bahasa Indonesia), distributed in hard copy and electronically (to access project newsletters visit www.csu. edu.au/research/ilws/researchers/race.htm).

\section{Research aim, data collection and analysis}

The key objectives of the research were to:

1. explore the experiences of the partners involved in different partnership arrangements for commercial forestry; and

2. identify the elements of 'successful' partnerships.

The research team followed accepted methods for social science (Blaikie 1993, Denzin and Lincoln 2000, Giddens 2004, Minichiello et al. 1995) and participatory cost-benefit analysis (Perkins 1999). The principal research techniques for collecting data for this research included:

- structured and semi-structured interviews;

- numerical cost-benefit analysis; and

- stakeholder meetings.

Structured interviews were conducted with farmers and forest growers, district forest agency staff, and forest company staff primarily to obtain numerical data on the growth rate of forest species, labour inputs, and financial costs and returns. This data provided the baseline information on which the cost-benefit analyses were conducted.

Semi-structured interviews were also conducted with a wide range of stakeholders directly involved in, or with previous experience of, forestry operations and contractual partnerships (approximately 100 people interviewed across the three locations). The interviews were framed by questions designed to explore the interviewees' perceptions of the nature of the partnership (i.e. what were the inputs and expected returns), was the partnership 'successful' (i.e. did it meet their expectations), and what partnerships would they enter into in the future (i.e. what would be their preferred partnership). All interviewers were trained in social science methods and were familiar with the local community and forestry context in the three locations. 
The analyses of the costs and benefits of forestry operations - for each partner - were undertaken using locally-derived input data (i.e. collected from people directly involved in local forestry operations, as small-scale growers, district forest officers, forest company staff). All data were converted to a single monetary unit for analysis (e.g. time of a farmer's labour was converted to an hourly payment, reduction in agricultural production was estimated in terms of the price value of lost yield). Original data was later confirmed at meetings of local stakeholders (e.g. growers, agency and company staff) before undertaking a final costbenefit analysis.

Stakeholder meetings were also convened to communicate and discuss the results of the cost-benefit analyses, the implications of the findings for partnerships, and how improved contractual partnerships might be developed in the future.

\section{Calculating components of forestry partnerships}

Even within a single district, there can be a wide variety of partnership arrangements for commercial forestry generating a mix of outcomes for small-scale growers, companies and government agencies - it appears that there is not a single partnership model that suits everyone.

The authors' research found that the variation in partnership arrangements was a challenge for researchers attempting to calculate all the costs and benefits. For example, many of the contributions to forestry partnerships do not involve explicit financial payments, so it was difficult to find accurate records of every input and return under different partnership arrangements. This made it difficult for the researchers to identify accurate figures for all inputs and benefits - which are needed when attempting to fully understand the outcomes of forestry partnerships for different stakeholders.

For example, farmers may harvest grasses for fodder or graze directly with livestock in forests - providing an important source of fodder, as well as weed and fire control for forestry. Also, company staff can provide critical market and silvicultural information to farmers, and agency staff can assist with overall catchment (watershed) planning for sustainable and productive forestry. All valuable contributions where people are often not paid, which made it difficult for researchers to take account of.

Costing the typically 'un-costed' inputs and returns is necessary if to inform people of the opportunity costs of investing their time and other resources in commercial forestry - allowing them explore what the tradeoffs might be, or better ways of undertaking commercial forestry. Small-scale growers in partnerships with forest companies, or government forest agencies, may obtain: income diversity, income security, secure land tenure, and access to non-timber forest products (e.g. vegetables and medicinal herbs, fodder for livestock, building materials). Indeed, the authors' research indicated that the financial returns may not represent the major benefits for some rural communities. In situations where financial returns from community- owned assets can be difficult to manage fairly and invest for sustained livelihood benefits, non-financial returns from forestry partnerships may deliver stronger social outcomes [Box 2 and 3].

\section{BOX 2 Findings from Sumbawa}

While the results indicated marginally positive benefitcost ratios of 1.06 (Semamung village) and 1.08 (Lamenta village) for some partnership arrangements, it also revealed that the local communities can incur higher costs under current arrangements than many partners were aware of, such as a greater time to meet their responsibilities for silviculture and protection of forest resources than anticipated. These results have been helpful for the local farmer forest groups to negotiate a higher proportion of the revenue when harvesting of the teak plantations occurs - as much as 93 percent (Semamung) and 98 percent (Lamenta) of revenue for the local community.

However, the research showed that even if all partners agree to revenue sharing based on the results of detailed cost-benefit analysis, the local community can remain at risk of not receiving the expected revenue in the long-term due to:

- insecure rights to forest resources (i.e. lack of resource tenure),

- a decline in the forest's yield and quality (e.g. insect predation, prolonged periods of low rainfall), or

- an under-estimation of the time required for teak plantations to reach maturity (e.g. due to lack of local data for modelling growth projections)

\section{BOX 3 Findings from Bulukumba}

The research team's cost-benefit analysis revealed several fundamental challenges for small-scale growers using the informal (verbal agreement) partnership arrangement in the Bulukumba district. The cost-benefit analysis indicated that the current partnership arrangement was marginal or not financially profitable (i.e. direct financial expenses exceeded expected income) for the small-scale growers in the villages of Balong and Karasing. Even when smallscale growers are given tree seedlings for free, they incur much of the labour costs and the high administration costs at harvest.

Furthermore, small-scale growers appear disadvantaged because they tend to have little knowledge of the seasonal variation in market demand, and of the commercial value of different log species and grades - putting them in the position of being a 'price taker'. The authors argue that these challenges need to be addressed before community-based forestry can be expected to make a positive and sustained contribution to the livelihoods of farmers in Bulukumba. 


\section{KEY FINDINGS}

\section{Negotiating long-term contracts in a dynamic context}

The research team focused on understanding the different perspectives of the existing partnerships by all parties involved. While appreciating that different parties form partnerships for a variety of reasons, the underlying ideal is that contractual partnerships will be beneficial and fair, and meet the expectations of all partners. However, during this research it emerged that this ideal can be problematic in the forestry sector for a number of reasons, including:

- the long period between establishing and harvesting plantations, with price changes,

- the difficulty in identifying 'real' market prices given the variation in growing, harvesting and transporting timber, and confidential nature of timber sales,

- fluctuating prices for food crops and livestock, altering the opportunity costs of growing trees for timber,

- changes in priority for households of farmers and companies,

- partners having unequal capacity to negotiate the terms of contract, and

- government policies at the district/local, provincial/ state and national levels are not always consistently in favour of commercial forestry (e.g. if it reduces the arable area for food crops).

Given the long-term nature of forestry compared to most agricultural commodity enterprises, it appears inherently difficult for farmers (particularly subsistence farmers with few financial or food reserves) to negotiate contracts that will remain 'successful', from their perspective, over several decades. At the very least, it would appear that long-term contracts hold a higher level of commercial and livelihood risk for all partners, compared to short-term contracts

\section{Potential benefits of the 'middleman'}

The research team's information highlighted that smallscale growers in Indonesia are often highly dependent on the intermediary broker ('middleman') for access to commercial markets, and there is a common view that the 'middleman' receives an unfairly high price compared to small-scale growers for organising the harvest and transport of timber from forests to processors [Box 4]. However, comparative analysis of the situation in Australia indicates that the intermediary broker ('middleman') can play a critical link between inexperienced small-scale growers and the processing industry.

As is common in Indonesia, small-scale growers in Australia may only sell timber from their forests once every decade or less frequently. So for most small-scale growers, developing a high level of up-to-date knowledge about timber prices, potential buyers, harvesting and transport contractors can often be unrealistic - especially if it is just needed for a relatively small sale every 10 to 20 years. As

\section{BOX 4 Findings from Bulukumba}

Results from the research team's analysis indicate that the price margin (profit) received by small-scale growers was the same for all distribution lines for logs of the same species and grade - and is approximately 10-18 percent of the overall value. The results also showed that the 'middleman' received the highest proportion of the value generated from timber production, with approximately 50 percent derived from teak and up to 84 percent from mixed species.

While at a superficial level it often appears advantageous for small-scale growers to establish direct partnership arrangements directly with processors to reduce the distribution stages and increase the profit margin for themselves, this isn't always straightforward. Typically, small-scale growers would need to substantially increase their knowledge about silviculture, log mensuration and grading, undertake the administration for harvesting and selling timber, and engage skilled harvesting and haulage contractors (or acquire this equipment and skills themselves) - all tasks currently undertaken by the 'middlemen'.

such, by contracting a broker to act on their behalf, smallscale growers are able to have an experienced advocate and informed negotiator working in the market place for them - with sufficient commercial incentive for the broker to maximise the returns for the grower.

Most small-scale growers in Australia contract a professional forester or forest consulting firm as an intermediary broker, to provide some or all of the following services:

- pre-harvest inventory of the extent and quality of the forest,

- undertake the administration to ensure all legal requirements are met (e.g. harvest plans registered with local government),

- negotiate the sales contract with the buyer,

- arrange and supervise the harvest and transport operations,

- audit logs on delivery to mill door.

Most intermediary brokers working on behalf of growers in Australia are paid by either:

- a commission based on the value of the total timber sold (e.g. 2-5 percent of the financial return to the grower); or

- a flat rate per unit of product harvested (e.g. Au\$1/ tonne).

\section{'Checklist' for partnerships}

To help summarise a wide range of experiences, theoretical concepts, and research results, the authors have prepared a 'checklist' of the key attributes of fair and beneficial partnership arrangements in the forestry sector [Box 5]. The authors suggest that if these attributes are met, then a partnership arrangement is likely to be positive for all partners. 


\section{BOX 5 Partnership 'checklist'}

1. All stakeholders are well-informed of opportunities, risks and costs (e.g. anticipated fees and other expenses);

2. Reliable markets identified;

3. Growers have secure land/forest tenure (recognised use or ownership of land or forest);

4. 'Best bet' farm and forest management is consistent with credible research and development and local field experience;

5. All partners are voluntarily entering into agreements;

6. Agreements are secure (recognised legal foundation);

7. Neighbourhood and off-site impacts considered and managed;

8. Supportive government policies and programs;

9. Agreed process for dispute resolution;

10. Work plans reviewed regularly and changes mutually agreed.

In many respects, the elements of the 'checklist' are generic to any partnership, so could potentially be applied to other sectors.

\section{DISCUSSION}

\section{Value chain analysis}

The results from this research indicates that the concept of a forestry value chain (i.e. activities that create and build value in forest products) can be a useful way of analysing the partnership arrangements for the different partners involved, including small-scale growers. With specific reference to the small-scale growers in the Sumbawa district, an analysis showed that the growers, who have traditionally sold logs on the 'stump' to intermediary brokers ('middlemen'), could be involved in other activities along the forestry value chain to increase the profits from their forests.

For example, rather than just selling logs as they stand in the forest ('stumpage sales'), they could participate in harvesting and haulage, and sell logs at other market points (e.g. at the roadside, or delivered to sawmills) on a profitable basis. They could also form grower cooperatives, develop marketing joint ventures, or contract a market broker to work on their behalf (rather than as an independent 'middleman') as means of obtaining better prices and therefore adding value to their forest products.

Market transparency is also an important factor to allow small-scale growers to realise fair prices for their forest products. These and other considerations highlight the importance of improving the knowledge of small-scale growers of the different components of the forestry value chain, so they can make an informed decision about their investment in commercial forestry.

\section{Simplified regulatory processes needed}

The authors' research revealed that most small-scale growers harvest timber infrequently and make just a few transactions in forestry markets in a lifetime. Unreliable market information, and excessive and complex bureaucratic processes ('red tape') can lead small-scale growers to undervalue their forests and sell to disreputable 'middlemen'. It can also increase the attraction of selling timber via cheaper and less complicated means (e.g. cash sales without permits), even if illegal.

Access to credible information about local markets, and an easy and transparent regulatory process for selling forest products are essential if to encourage small-scale growers to commit to commercial forestry over the long-term.

\section{Social capital critical for farmer forest groups}

Published literature indicates a strong correlation between high levels of 'social capital' (i.e. cooperative relationships between people in a community) and people with healthy and resilient livelihoods (Pretty and Ward 2001, Pretty 2003, Cramb 2006). The authors' research is consistent with this view, and indicates the social capital of farmer forest groups (village-level groups of small-scale growers) as a critical requirement for improving the capacity for small-scale growers to negotiate beneficial partnership arrangements and in turn, improve the returns from commercial forestry. The elements of social capital important to the farmer forest groups in the three locations covered by this research included:

- leadership qualities (e.g. ability to motivate members, act as a representative, engage outside expertise and organisations),

- support for members and group cohesion,

- knowledge generation and exchange,

- capacity to develop and manage community-based enterprises, and

- collective confidence and skills to negotiate with outside organisations (e.g. companies, government).

However, social capital is a complex concept and it also includes community relationships that discourage or inhibit innovation and new ideas, and restrict the involvement of marginalised people in a community's influential groups and networks (Grootaert 2001, Pretty 2003). Understanding the important characteristics of social capital that helps small-scale growers to negotiate beneficial partnership arrangements with other partners is required.

In particular, how social capital can:

- improve small-scale growers' analytical capacity of commercial forestry's value-chain;

- increase the capacity and willingness of small-scale growers to share information and expertise; and

- improve the negotiation skills of all partners involved in partnership arrangements.

\section{Social 'licence to operate' for forestry}

Even if forestry practices are commercially productive and legal, and small-scale growers and processors have 
a firm agreement, if the wider community has serious concerns about the impacts of commercial forestry then they can restrict the activity and scale of forestry. As such, there appears value in ensuring partnership arrangements are seen publicly to be fair and beneficial for small-scale growers and for those beyond the immediate partnership. Maintaining the social 'licence to operate' for forestry (i.e. acceptance of forestry by the wider community) - at the district, regional and international levels - has grown in importance. Formal certification of sustainable forestry is one response to encourage forest managers to meet community expectations (e.g. 'Woodmark' as offered by the Forest Stewardship Council), so ensuring partnership arrangements are compliant with the prevailing expectations of 'best practice' forestry will be valuable for all partners.

In Australia, leading plantation management companies have adapted and changed their business to accommodate various community concerns, with the aim that current forestry practices meet community expectations and they maintain their 'licence to operate' - with partnership arrangements with local landholders an important part of that strategy [Box 6].

\section{BOX 6 Findings from the Green Triangle}

In Australia, the wide variety of partnership arrangements have been used, including 'land leasing', 'crop share' and 'marketing' agreements. 'Land leasing' arrangements (i.e. farmers paid a secure land rent over 10-20 years for companies to access farmland to grow plantations) have been the most common partnership arrangement since the mid-1990s. However, despite this being stated as the preferred partnership model for several companies, commercial forestry still only appeals to a small minority of landholders - with most landholders not engaged in commercial forestry. In response, companies continue to design new, and refine existing, partnership arrangements thought to be more attractive to farmers (e.g. offering higher rental payments, more flexible terms).

This research indicates that the dynamic nature of the social and economic context for commercial forestry needs to be reflected in the partnership arrangements, such as by allowing regular reviews and offering scope for adaptation to meet the changing community expectations, policy context and commercial opportunities.

The results from the three-year research project reported in this article - focused on partnership arrangements in three locations (the Green Triangle region in south-east Australia, Sumbawa district in West Nusa Tenggara province, and Bulukumba district in South Sulawesi province, Indonesia), revealed that different partners can often have very different expectations - of commercial forestry and the partnership itself.

In the Green Triangle region, partnership arrangements between individual landholders (with secure tenure of their farmland) and forestry companies that provided regular and indexed lease payments to landholders remain the most common model. However, 'second generation' arrangements (i.e. partners entering into a contract after the conclusion of an initial contract) were becoming more flexible in nature and when payments are made to landholders, such as financial payments and other goods (e.g. fencing, additional trees) provided on a regular basis, or lumped at specific times during the contract. It appears that the flexibility of second generation arrangements (contracts) was possible after a strong and trusted relationship had been established between the partners, usually via an initial 'successful' partnership. Second generation arrangements are particularly attractive to companies as there tend to be lower transaction (e.g. less time required to inform landholders about forestry operations, less 'red tape' incurred about native vegetation restrictions) and lower operating costs (e.g. roads for harvesting and transport established). Given most forestry partnership arrangements in the Green Triangle region where the research team was active are still to reach maturity, second generation contracts have only recently emerged, so further research of these would be informative.

\section{CONCLUSION}

This research revealed that small-scale growers often lack an understanding of the value (costs and benefits) of different components of commercial forestry, have a poor knowledge of market prices, and have weak links to competitive markets - causing them to be unable to negotiate fair and beneficial agreements. This key finding is consistent with other international research on related topics.

This research also identified that greater investment is needed to empower small-scale growers, so that commercial forestry becomes a pathway out of poverty for rural communities - not part of the poverty cycle. Greater investment and support is needed by existing and prospective small-scale growers and other stakeholders (e.g. local agency and company staff) so they achieve:

- Increased knowledge of the operations and components of commercial forestry (e.g. awareness of forestry's value-chain);

- Improved understanding of the direct and indirect costs and returns of commercial forestry (e.g. rigorous $\mathrm{CBA}$ to identify net returns and opportunity costs);

- Improved access to competitive markets (e.g. potential for small-scale growers to contract intermediary brokers or form cooperatives);

- Increased knowledge of market dynamics (e.g. drivers of market fluctuations, awareness of market prices);

- Improved capacity and willingness of farmer forest groups to share experiences and information, and create new knowledge of commercial forestry (e.g. build the social capital of farmer groups); and

- Reduced administrative and financial burden imposed by governments on small-scale growers (e.g. simplify regulations and streamline the processes for permits). 
Failure to develop partnership arrangements that are mutually beneficial, fair and sustainable can have profound impacts - with flawed arrangements in commercial forestry a contributor to illegal forestry, undesirable deforestation, rural poverty and community conflict. For example, poor farmers who are locked into contracts that do not deliver fair prices are vulnerable to being tempted by the financial returns of short-term and exploitive forestry, even if their activities are illegal. Achieving a symmetry in power between partners, and ensuring commercial forestry exists within a supportive commercial, regulatory, and social context, will provide a strong likelihood that partnership arrangements will be positive - that is, partnerships that are beneficial, fair and enduring.

Navigating the complexity of government policies and regulations, changing community values toward forestry, and establishing forests that will be in demand in 20 to 30 years time is the challenge for all investors - large and small, public and private. However, the authors suggest that partnership arrangements that meet the 'checklist' noted in this article are likely to stand the test of time, and lead to forestry that is successful for all partners.

\section{ACKNOWLEDGEMENT}

The authors thank Dr R.J. (Bob) Fisher for his helpful comments on an early draft of this article. The authors also appreciate the valuable advice provided by three anonymous reviewers on a draft of the article. Dr Russell Haines (ACIAR) provided helpful comments on research reports upon which much of this article is based.

The authors would like to note that the views expressed in this article are solely the authors, and do not necessarily reflect the views of the many people and organisations involved in the research.

\section{REFERENCES}

ARNOLD, M. 1997. Trees as outgrower crops for forest industries: experience from the Philippines and South Africa. Rural Development Forestry Network, Network Paper 22a (winter 1997/98). Overseas Development Institute, London, UK.

BLAIKIE, N. 1993. Approaches to social enquiry. Polity Press/Blackwell, Cambridge, UK.

CRAMB, R.A. 2006. The role of social capital in the promotion of conservation farming: the case of landscare in the southern Philippines. Land Degradation and Development 17: 23-30.

CURTIS, A. and RACE, D. 1998. Links between farm forestry growers and the wood processing industry: Lessons from the Green triangle, Tasmania and Western Australia. Report for Rural Industries Research and Development Corporation (RIRDC), RIRDC Publication No. 98/41, Canberra, ACT.

DENZIN, N.K. and LINCOLN, Y.S. (eds) 2000. Handbook of qualitative research. $2^{\text {nd }}$ edition, Sage Publications Inc, Thousand Oaks, USA.

DESMOND, H. and RACE, D. 2000. International review of forestry Out-grower schemes. Report for Food and Agriculture Organisation. Australian National University, Canberra, ACT.

GIDDENS, A. 2004. Introduction to sociology. $4^{\text {th }}$ edition, Polity Press, UK.

GRAY, I. and LAWRENCE, G. 2001. A future for regional Australia: escaping global misfortune. Cambridge University Press, UK.

GROOTAERT, C. 2001. Social capital: The missing link? In: P. Dekker and E.M. Uslaner (eds) Social Capital and Participation in Everyday Life: 9-29. Routledge, USA.

MAKARABHIROM, P. and MOCHIDA, H. 1999. A study on contract tree farming in Thailand. Bulletin of Tsukuba University Forest 15 (March), Thailand.

MAVHUNGA, C. 2007. Even the rider and a horse are a partnership: a response to Vermeulen and Sheil. Oryx 41: 441-442.

MAYERS, J. 2000. Company - community forestry partnerships: a growing phenomenon. Unasylva 51 (1): 33-41.

MAYERS, J. and VERMEULEN, S. 2002. Companycommunity forestry partnerships: from raw deals to mutual gains? International Institute for Environment and Development, London, UK.

MINICHIELLO, V., ARONE, R., TIMEWELL, E. and ALEXANDER, L. 1995. In-depth interviewing: researching people. Longman, Cheshire, Melbourne, Australia.

NAWIR, A.A. and SANTOSO, L. 2005. Mutually beneficial company-community partnerships in plantation development: emerging lessons from Indonesia. International Forestry Review 7 (3): 177-192.

NAWIR, A.A., SANTOSO, L. and MUDHOFAR, I. 2003. Towards mutually-beneficial company-community partnerships in timber plantation: lessons learnt from Indonesia. Research Report, Center for International Forestry Research, Bogor, Indonesia.

PATRICK, I. 2004. Contract farming in Indonesia: Smallholders and agribusiness working together. ACIAR Technical Report 54, Australian Centre for International Agricultural Research (ACIAR), Canberra, ACT.

PERKINS, F. 1994. Practical cost benefit analysis: basic concepts and applications. Macmillan, Education Australia, Melbourne, Australia.

PRETTY, J. 2003. Social capital and the collective management of resources. Science 302: 1912-1914.

PRETTY, J. and WARD, H. 2001. Social capital and the environment. World Development 29 (2): 209-227.

RACE, D. and CURTIS, A. 1999. Farm forestry in Australia: Improving links between small-scale growers and industry. Journal of Sustainable Agriculture 13 (4): $67-$ 86.

RACE, D. and DESMOND, H. 2002. Forestry outgrower schemes: a review from selected countries. Journal of Sustainable Forestry 15 (4): 79-98. 
ROBINSON, J.G. 2007. Recognising differences and establishing clear-eyed partnerships: a response to Vermeulen and Sheil. Oryx 41 (4): 443-444.

THOMS, C.A., KARNA, B.K. and KARMACHARYA, M.B. 2006. Limitations of leasehold forestry for poverty alleviation in Nepal. Society and Natural Resources 19: 931-938.

VERMEULEN, S. and SHEIL, D. 2007. Partnerships for tropical conservation. Oryx 41 (4): 434-440. 